\title{
Derelikce nemovitosti a její právněhistorické kořeny
}

\author{
Marek Novák
}

Právnická fakulta, Univerzita Karlova

Kontaktnie-mail:novakm29@prf.cuni.cz

\section{Dereliction of Real Estate and Its Legal-Historical Origins}

\begin{abstract}
:
It follows from the case law of the Supreme Court and Constitutional Court that everyone has the right to leave immovable property if they do not illegally avoid liability for non-fulfilment of their own obligations. The legal institute of dereliction has its origins in Roman law, which emphasized the free will of the owner deciding to abandon property. The dereliction of real estate according to the Civil Code in effect takes place by the legal action itself, by which the owner expresses the will to abandon the thing. Declaratory nature of property registration in the real estate cadastre might follow the recodification work in the 1920s and 1930s, as it differs from the General civil code (ABGB) regulation. Moreover, the Civil Code is influenced by socialist legislation when it transfers abandoned real estate to state ownership automatically. Although this was originally considered a measure in favour of the society, it is likely to cause difficulties. In recent years, laconic provisions of the Civil Code have provoked a discussion on the requisites of the application for the registration of state ownership in the real estate cadastre in case of dereliction. The cadastral offices and some courts initially considered that the application must be accompanied by a consent statement from the original owner and the state, which, however, contradicts the characteristic of dereliction as a unilateral act. The Supreme Court strongly opposed this practice and interpreted the nature of dereliction in its decisions in detail.
\end{abstract}

Keywords: dereliction; real estate; proprietary right; Roman law; Civil Code; case law

Klíčová slova: derelikce; nemovitost; vlastnické právo; rrímské právo; občanský zákoník; judikatura

DOI: $10.14712 / 2464689 X .2021 .22$

Financování: Tento výstup vznikl na základě finanční podpory v rámci projektu č. 254319 Grantové agentury UK. 
Rekodifikace občanského práva v České republice vyvolala polemiku nad tím, zda a za jakých podmínek je možné vzdát se vlastnického práva k nemovitostem, neboli nemovitosti s právními důsledky opustit. Nejistotu podpořily stručné formulace občanského zákoníku, ${ }^{1}$ který se derelikci nevěnuje samostatně a zmiňuje se o tomto oprávnění vlastníka téměř mimochodem, když blíže specifikuje přivlastnění věci. V ustanovení $§ 1045$ odst. $1 \mathrm{OZ}$ jsou opuštěné movité věci zařazeny mezi res nullius: „Věc, která nikomu nepatř́, si každý může přivlastnit, nebrání-li tomu zákon nebo právo jiného na přivlastnění věci. Movitá věc, kterou vlastník opustil, protože ji nechce jako svou držet, nikomu nepatř́i.“ Možnost derelikce nemovitostí pak vyplývá pouze implicitně z lakonického ustanovení § 1045 odst. 2 OZ: „Opuštěná nemovitá věc připadá do vlastnictví státu.“ Nejde přitom jen o čistě akademickou otázku. Katastrální úřady od počátku účinnosti OZ v lednu 2014 evidují již přes 30 návrhů na vklad vlastnického práva státu k pozemkům nebo stavbám v důsledku vzdání se vlastnického práva. ${ }^{2}$ Svérázná interpretace úruadů i obecných soudů navíc v prvních letech provedení derelikce prakticky blokovala a odhalila tak v plném světle nedůslednost zákonodárce.

Zdá se však, že představa opuštění nemovitosti vyvolávala v českém právu pochybnosti odjakživa a mnohdy ani nepanovala shoda na tom, zda je takový postup vůbec př́ípustný. Civilní kodexy v tomto ohledu trpěly podstatnými mezerami, právní teorie 19. a 20. století zaujímala rozličná stanoviska. Pak je vhodnou inspirací poohlédnout se v pramenech římského práva, ostatně institut derelikce dnešní právo ze starověkého Ríma převzalo. Tak bude postupovat i tento text, který nahlédne do pomyslných kořenů současné občanskoprávní kodifikace. Zaměří se přitom na zodpovězení otázek, jaké účinky derelikce vyvolávala, a kdy přesně k nim docházelo. Dále článek v kontextu historického vývoje představí současnou právní úpravu derelikce nemovitosti a nedávný obrat v praxi katastrálních úřadů i soudního rozhodování, který vedl k ustálení poměrů a svým způsobem už také náleží historii.

\section{Právní povaha derelikce}

V pramenech římského práva sice převažují texty, jež se výslovně věnují derelikci movitých věcí, není ale pochyb o tom, že bylo možné opustit i nemovitosti. ${ }^{3} \mathrm{Z}$ dostupných předpisů lze vyvodit obecně platné principy, kterými se derelikce v antickém Římě řídila. Do popředí přitom vystupuje nesmlouvaný důraz na svobodnou vůli dosavadního vlastníka, jež podobně jako v ustanovení $§ 1045$ odst. 1 OZ sama o sobě působí pozbytí vlastnického práva. Člověk provádějící okupaci mohl nabýt zdánlivě opuštěnou věc pro sebe jen za předpokladu, že ji její původní vlastník za derelikvovanou skutečně považoval na základě vlastního rozhodnutí: ...pro derelicto autem habetur, quod dominus ea mente abiecerit, ut

\section{Zákon č. 89/2012 Sb., občanský zákoník (OZ).}

2 Statistika Českého úřadu zeměměřického a katastrálního poskytnutá podle zákona č. 106/1999 Sb., o svobodném př́stupu $\mathrm{k}$ informacím. Na základě derelikce nemovitosti nebyl v letech 2014 a 2015 podán žádný návrh na vklad, v roce 20166 návrhů, v letech 2017 a 2018 shodně po 7 návrzích, v roce 20198 návrhů, v prvním pololetí roku 2020 pak 3 návrhy. ČÚZK vykazuje za období od ledna 2014 do července 2020 celkem 31 podaných návrhů. Zdá se, že toto číslo bude ve skutečnosti vyšší, protože úřad prokazatelně některé podané návrhy do statistiky z neznámých důvodů nezahrnul.

3 Srov. KASER, M. Das römische Privatrecht, Erster Abschnitt. München: C. H. Beck, 1971, s. 426. Srov. HAUSMANINGER, H. - SELB, W. Römisches Privatrecht. Wien - Köln - Weimar: Böhlau, 2001, s. 159. 
id rerum suaram esse nollet... ${ }^{4}$ Ke ztrátě vlastnictví nedocházelo v situacích, kdy se sice vlastník vnějšími projevy zbavoval fyzického ovládání věci, ale bylo zároveň zjevné, že tak činí nedobrovolně či z nouze. Jako př́klad takového jednání lze spatřovat vyhazování věcí z lodi, jíž hrozí potopení. V každodenní realitě starověkého Říma šlo patrně o častý jev, nebot' je mu věnována značná pozornost: Alia causa est earum rerum quae in tempestate maris levandae navis causa eiciuntur. hae enim dominorum permanent, quia palam est, eas non eo animo eici quo quis eas habere non vult, sed quo magis cum ipsa navi periculum maris effugiat: qua de causa si quis eas fluctibus expulsas vel etiam in ipso mari nactus lucrandi animo abstulerit, furtum committit. Nec longe discedere videntur ab his quae de rheda currente, non intellegentibus dominis, cadunt. ${ }^{5}$ Pokud vyhazování věcí z lodi představovalo způsob jejich záchrany, chyběl jistě úmysl vlastníka pozbýt vlastnické právo. Situace je přirovnávána k cestování po silnici, kdy mohlo zboží bez vědomí vlastníka vypadnout z povozu, nebo kdy obchodník u cesty záměrně odloží část svého tíživého nákladu, aby si mohl přivolat pomoc a vrátit se pro něj s posilami: ...ut perinde sint, ac si quis onere pressus in viam rem abiecerit mox cum aliis reversurus, ut eandem auferret. ${ }^{6}$

Zobecněná zkušenost velela, že věci mořem vyplavené nebo v něm plovoucí nebyly obvykle opuštěny na základě svobodné volby jejich vlastníka, a proto justiniánské Instituce nepřipouštěly, aby nálezce bez dalšího presumoval jejich derelikci. Nenabyl takové věci do vlastnictví, a jestliže navíc věděl o jejich skutečném původu, bylo lze jeho jednání kvalifikovat jako krádež. ${ }^{7}$ Ulpianus však zároveň nevylučuje případy, kdy původní vlastník vyhodil věc z lodi svobodně a úmyslně, nikoli v nouzi. Pak byla derelikce samozřejmě platná, res nullius byla volná k okupaci a nálezce krádež nepáchal.

Mimo hladinu moře dovozoval nálezce existenci vůle pưvodního vlastníka věc opustit z jeho jednání ve vnějším světě. Rozhodl-li se dosavadní vlastník věc opustit, musel svou vůli projevit navenek. Svědčily-li okolnosti o tom, že věc byla opuštěna, nemusel její nálezce zkoumat, kdo přesně ji opustil a za jakých okolností: Id, quod pro derelicto habitum est et haberi putamus, usucapere possumus, etiam si ignoramus, a quo derelictum sit. ${ }^{8}$ Nicméně, byla-li domněnka nálezce o provedení derelikce nesprávná a dosavadní vlastník neměl v úmyslu se svého práva vzdát, nemohl ji získat pro sebe a vlastnické právo trvalo

4 Inst. Iust. 2, 1, 47: ,...Za opuštěné je považováno to, čeho se vlastník zbavil s úmyslem, aby to více nebylo součástí jeho majetku..." Veškeré překlady justiniánských Institucí jsou převzaty z publikace Iustiniani Institutiones. Praha: Karolinum, 2010. Viz D. 41, 7, 2pr. (Paul. 54 ad ed.).

5 Inst. Iust. 2, 1, 48: „Jinak je to s věcmi, které jsou vyhozeny z paluby lodě do moře za neprríznivého počasí proto, aby se lod' odlehčila. Tyto věci zůstávají vlastníkovi z toho důvodu, nebot' nebyly z lodě vyhozeny s tím záměrem, že by je vlastník již nechtěl mít, ale byly vyhozeny proto, aby lod' lépe odolávala nebezpečí moře. Ten, kdo si takovéto věci vyplavené z moře na pobřeží, nebo nacházející se na otevřeném moři, ponechá s úmyslem se obohatit, dopustí se krádeže. Tyto věci se bezesporu neodlišují od věcí, které vypadly z jedoucího vozu, aniž by si toho vlastník všimnul." Viz D. 41, 1, 9, 8 (Gai 2 rer. cott.), D. 41, 7, 7 (Iul. 2 ex minic.), D. 41, 2, 21, 1 (Iavol. 7 ex cass.), D. 41, 2, 212 (Iavol. 7 ex cass.), D. 14, 2, 2,8 (Paul. 34 ad ed.).

6 D. 14, 2, 8 (Iul. 2 ex minic.): ,...Je to stejné, jako kdyby někdo obtěžkán nákladem nechal věc ležet na cestě s tím, že se brzy s dalšími [lidmi] vrátí, aby ji odnesl.“

7 D. 47, 2, 43, 11 (Ulp. 41 ad sab.), D. 41, 1, 58 (Iavol. 11 ex cass.).

8 D. 41, 7, 4 (Paul. 15 ad sab.): „To, co je považováno za opuštěné a my to [za opuštěné] považujeme, můžeme vydržet, také když nevíme, kým to bylo opuštěné.“ 
beze změny: Nemo potest pro derelicto usucapere, qui falso existimaverit rem pro derelicto habitam esse. ${ }^{9}$

V Digestech lze dohledat také několik fragmentů, které hodnotí přípustnost derelikce nemovitosti. Zabývají se jí v kontextu jiných právních institutů a naznačují, že v římském právu byl dán pro opuštění nemovitosti poměrně široký prostor. Např́iklad v souvislosti s definicí služebnosti nesení břemene (servitus oneris ferendi), která netypicky ukládala vlastníkovi služebného pozemku povinnost aktivně udržovat podpěru stavby, Ulpianus zdůraznil, že se služebnost vztahovala k věci, nikoli k osobě, a proto mohla povinná osoba služebný pozemek dle libosti opustit. ${ }^{10}$ Dále byla možnost derelikce přiznána vlastníkovi stavby, která se zrrítila na sousední pozemek a způsobila škodu. Pokud se vlastník stavby před jejím zrrícením nezavázal k náhradě budoucí škody (cautio damni infecti), měl na výběr, zda trosky dobrovolně odstraní, nebo se rozhodne zrrícenou stavbu jako celek opustit. Pak k odstranění trosek nemohl být donucen. ${ }^{11}$ Za pozornost stojí, že derelikce mohla být vnímána také jako jednání v úmyslu zkrátit věřitele (alienatio in fraudem creditorum). Věřitel se totiž mohl bránit před jakýmkoli způsobem zcizení majetku, včetně opuštění věci a jejímu přenechání jiným $\mathrm{k}$ volné okupaci. ${ }^{12}$ Je však nutno přiznat, že všechny tyto zmínky jsou pouze neprímé a o opuštění nemovitostí neposkytují plastický obrázek. Navíc není vždy jednoznačné, kdy lze výrazu opuštění věci v pramenech přiřadit jeho právnický význam pozbytí vlastnického práva, a kdy mají texty na mysli pouze faktické opuštění bez právních následků. Lze však uzavřít, že úryvky justiniánské kodifikace alespoň v obecné rovině činily každou derelikci úzce závislou na skutečném úmyslu dosavadního vlastníka věc opustit. Bez jeho zcela svobodného rozhodnutí nebyly žádné právní důsledky myslitelné, jeho existenci nebylo možné lehkovážně presumovat.

Na teorii římského práva navázaly novodobé občanskoprávní kodexy, když všechny principiálně připouštěly opuštění movitých i nemovitých věcí a vázaly je převážně na samotný projev vůle dosavadního vlastníka. Derelikce tedy byla možná, nicméně, její právní úprava obvykle trpěla značnými mezerami. Ty lze vypozorovat již v Obecném zákoníku občanském, ${ }^{13}$ prvním moderním občanskoprávním kodexu platném na území dnešní České republiky. V ustanovení § 386 ABGB byla upravena derelikce movitých věcí: „Movité věci, jež vlastník nechce již jako své podržeti a tedy opustí, může si každý

9 D. 41, 7, 6 (Iul. 3 ad urs. ferocem): „Kdo by omylem pokládal věc za opuštěnou, nemůže [ji] z důvodu derelikce vydržet."

10 D. 8, 5, 6, 2 (Ulp. 17 ad ed.): ...labeo autem hanc servitutem non hominem debere, sed rem, denique licere domino rem derelinquere scribit. „...Ale Labeo [ř́iká], že tato služebnost není určena člověku, nýbrž věci, takže, píše, vlastník smí věc opustit.“

11 D. 39, 2, 7, 2 (Ulp. 53 ad ed.): ...quod si dominus aedium, quae deciderunt, nihil facit, interdictum reddendum ei, in cuius aedes rudera decidissent, per quod vicinus compelletur aut tollere aut totas aedes pro derelicto habere. ,....Jestliže vlastník staveb, které se zř́itily, nic neudělá, interdikt má být dán tomu, na jehož dům se zřítily trosky, a jeho prostřednictvím bude soused nucen bud’ uklidit [trosky], nebo celý dům opustit."Viz D. 39, 2, 6 (Gai 1 ad ed. provinc.).

12 D. 42, 8, 4 (Paul. 68 ad ed.): In fraudem facere videri etiam eum, qui non facit quod debet facere, intellegendum est, id est si non utatur servitutibus: D. 42, 8, 5 (Gai 26 ad ed. provinc.): Sed et si rem suam pro derelicto habuerit, ut quis eam suam faciat. 4. „Zdá se, že ten, kdo nedělá to, co má dělat, jedná podvodně, například, když neužívá služebnosti.“ 5. „Ale i jestliže opustil svou věc, aby si ji mohl někdo jiný přivlastnit." Viz HEYROVSKÝ, L. Dějiny a systém soukromého práva řimského. Praha: Otto, 1910, s. 799 a násl.

13 Zákon č. 946/1811 ř. z., obecný zákoník občanský (ABGB). Účinný od 1. ledna 1812. 
př́islušník státu přivlastniti.“14 Následující ustanovení $§ 387$ ABGB pak výslovně zmiňovalo nemovitosti: „Pokud je pokládati pozemky pro naprosté opomenutí jejich vzdělávání nebo budovy pro opomenuté udržování za opuštěné nebo pokud mají býti odňaty, ustanovují zákony politické.“ Nepozorný čtenář mohl při pohledu na tuto dvojici ustanovení, společně zařazenou pod nadpis ,přivlastnění nálezem věcí ničích“, nabýt dojmu, že ve vzájemném kontrastu upravovala derelikci movitých a nemovitých věcí. Ostatně, takto $\mathrm{k}$ citovaným předpisům přistupoval i Zeillerův komentár. ${ }^{15}$ Civilisté nicméně většinovým názorem důrazně upozorňovali na to, že je takový pohled mylný. ${ }^{16} \mathrm{~V}$ ustanovení $§ 387$ ABGB se nejednalo o derelikci, nýbrž vyvlastnění majetku, nestaral-li se o něj vlastník řádným způsobem. O své vlastnické právo přicházel v důsledku opomenutí zákonných povinností bez toho, aby pojal úmysl se ho trvale vzdát. Pozbyl je v důsledku rozhodnutí př́slušného orgánu, nikoli projevem vlastní vůle. Šlo tedy o nástroj, kterým právo reagovalo na prŕípady zanedbání péče o nemovitosti, ustanovení $§ 387$ ABGB ale nijak neupravovalo derelikci nemovitosti, nelze z něj vyvodit, zda byla připuštěna nebo zakázána, případně, za jakých podmínek k ní mohlo dojít.

V ABGB bylo tedy výslovně pamatováno jen na derelikci movitých věcí. Z ustanovení § 444 ABGB, které v souvislosti s intabulační zásadou hovořilo o zániku vlastnictví „,vưlí vlastníka“, ve spojitosti s ustanovením § 362 ABGB, jež do výčtu obecných oprávnění vlastníka zahrnulo také opuštění věci, sice vyplývalo, že bylo možné derelikvovat také nemovitosti, podrobnější právní úprava ovšem chyběla. Teprve právní věda dovodila, jaké podmínky opuštění movitých věcí na ně bylo lze analogicky aplikovat. Je přitom patrné napětí mezi možností přenést ustanovení § 386 ABGB na nemovitosti v plném rozsahu, přestože jim není určeno, nebo naopak výslovným omezením tohoto ustanovení na movité věci odůvodňovat nutnost alespoň částečně odlišné právní úpravy. ${ }^{17}$ Nicméně, principiálně právní civilistika derelikci nemovitostí mimo explicitní úpravu ABGB shodně připouštěla a identifikovala ji jako jednostranné právní jednání, které není adresováno konkrétní osobě, ale musí být dostatečně určité, aby se o něm mohli dozvědět všichni relevantní aktéři. Právním jednáním byla projevena vůle opouštějícího vlastníka vzdát se svého práva, doprovázena ale musela být i vzdáním se držby. ${ }^{18} \mathrm{~V}$ pochybnostech se nepresumovalo, že by se někdo svého vlastnického práva vzdával. ${ }^{19}$ Movité i nemovité věci byly v soula-

14 Veškeré překlady ABGB jsou převzaty z databáze Beck online (www.beck-online.cz).

15 ZEILLER, F. von. Commentar über das allgemeine bürgerliche Gesetzbuch für die gesammten deutschen Erbländer der oesterreichischen Monarchie, zweyter Band, erste Abtheilung. Wien, Triest: Geistinger, 1812, s. 165-166. Ustanovení § 387 ABGB považuje za právní úpravu derelikce nemovitostí také Petr Baudyš a vyvozuje z něj, že nebyla chápána jako právní úkon, nýbrž faktický stav: BAUDYŠ, P. Opuštěná nemovitost. Právní rozhledy, 2005, 15, s. 563 a násl.

16 Zeillerův komentář v tomto ohledu kritizuje Jaromír Sedláček: SEDLÁČEK, J. Vlastnické právo. Komentár̆ $k$ §§ 353-446 všeob. obč. zák. se zřetelem ku právu na Slovensku a Podkarpatské Rusi platnému. Praha: V. Linhart, 1935, s. 361-362. Proti mylnému chápání ustanovení § 387 ABGB se shodně vymezují také další autoři: RANDA, A. Právo vlastnické dle rakouského práva v pořádku systematickém. Druhé opravené vydání. Praha: Edvard Grégr, 1874, s. 65. ROUČEK, F. - SEDLÁČEK, J. et al. Komentář k československému obecnému zákoniku občanskému a občanské právo platné na Slovensku a v Podkarpatské Rusi. Díl 2, (\$\$ 285 až 530). Praha: Linhart, 1935, s. 384-385.

17 Srov. ROUČEK - SEDLÁČEK et al., op. cit., s. 384.

18 RANDA, op. cit., s. 65, 153. SEDLÁČEK, op. cit., s. 218. ROUČEK - SEDLÁČEK et al., op. cit., s. 384-385.

$19 \S 388 \mathrm{ABGB}$. 
du s ustanovením $§ 386$ ABGB ponechány volně k okupaci ostatním občanům státu. Při pracích na rekodifikaci občanského práva ve 20. a 30. letech 20. století byly již předkládané návrhy upraveny, aby nebudily pochybnosti. Samotné znění návrhů i důvodové zprávy přistupovalo k možnosti derelikce nemovitých věcí jako k samozřejmosti, o níž není na místě pochybovat. ${ }^{20}$ Subkomitét pro revizi občanského zákoníku pak hned v prvním stádiu prací vypustil omezení okupace věcí ničích na státní občany. ${ }^{21}$

Podstatnou změnu přístupu přineslo socialistické zákonodárství. Občanský zákoník z roku $1950^{22}$ v ustanovení $§ 132$ odst. $1^{23}$ umožnil provedení derelikce movitých i nemovitých ${ }^{24}$ věcí, každá opuštěná věc však podle ustanovení § 119 OZ50 připadla ex lege státu: „Věci, které nenáležejí nikomu jinému, jsou ve vlastnictví státu, nemají-li cenu jen nepatrnou. K věcem nepatrné ceny, které nikomu nenáležejí, může nabýt vlastnického práva každý tím, že si je přivlastní.“ Oproti ABGB šlo o zásadní myšlenkový obrat, který důvodová zpráva připisovala opuštění liberalistických zásad vrozené volnosti a upřednostnění zájmu celku před zájmem jednotlivce. Rozšiřování státního majetku tedy bylo implicitně vnímáno jako společensky prospěšné. Občanský zákoník z roku 196425 ve znění účinném do 31. prosince 1991 tyto zásady ve stručněji vyjádřené podobě převzal. ${ }^{26}$ Zrušil do té doby existující výjimku pro věci nepatrné hodnoty, mezi něž však stejně není možné nemovitosti řadit. V důsledku právního jednání vlastníka, který se vzdával svého vlastnického práva, nabýval veškeré opuštěné věci na základě $§ 453$ odst. 2 OZ64 stát, soukromé osoby by jejich okupací získaly neoprávněný prospěch: „Věci opuštěné nebo skryté, jejichž vlastník není znám, připadají do vlastnictví státu. Kdo si je přisvojí nebo kdo jich užívá, je povinen státu je vydat, poprrípadě vydat i neoprávněný majetkový prospěch takto získaný.“ Při interpretaci citovaného ustanovení se objevila otázka, zda se podmínka, že vlastník věci není znám, vyžadovala vedle skrytých věcí i pro derelikci. Zatímco někteří autoři na tomto požadavku trvali, ${ }^{27}$ což by fakticky derelikci vytlačilo z praxe, Nejvyšší soud Slovenské socialistické republiky konstatoval, že ,zákonná požiadavka, aby vlastník veci nebol známy, vzt’ahuje sa iba na veci skryté a nie na veci opustené“. ${ }^{28}$ Ke stejnému

20 STIEBER, M. Věcné právo, Návrh subkomitétu pro revisi občanského zákonika pro Československou republiku. Praha: Nákladem ministerstva spravedlnosti, 1923, s. 23, 24 (§ 386-387). Zákon, kterým se vydává všeobecný zákoník občanský: návrh superrevisní komise. Díl I. Tekst zákona. V Praze: Nákladem ministerstva spravedlnosti, 1931, s. 89 (§ 300-301). Senát Národního shromáždění R. Čs. r. 1937, tisk 425, vládní návrh zákona, kterým se vydává občanský zákoník. Dostupné na: http://www.senat.cz/informace /z_historie/tisky/4vo/tisky/T0425_01.htm (§ 158-159). Návrhy rekodifikace se však lišily v některých dílčích pravidlech, o této otázce je pojednáno níže.

21 STIEBER, op. cit., s. 23, 24, 84.

22 Zákon č. 141/1950 Sb., občanský zákoník (OZ50). Účinný od 1. ledna 1951.

$23 \S 132$ odst. 1 OZ50: „Vlastnictví se pozbývá zejména také tím, že ho nabude někdo jiný nebo že se ho vlastník vzdá."

24 Srov. usnesení Nejvyššího soudu ze dne 22. července 2015, sp. zn. 22 Cdo 5163/2014; 22 Cdo 910/2015, [PR 4/2017 s. 149].

25 Zákon č. 40/1964 Sb., občanský zákoník (OZ64). Účinný od 1. dubna 1964.

26 Rozsudek Nejvyššího soudu ze dne 13. dubna 2000, sp. zn. 22 Cdo 2326/98, [SR 7/2000 s. 205].

27 CHALUPA, L. K zániku vlastnictví nemovitosti opušténím a vzdáním se vlastnického práva. ASPI, 3. dubna 2001.

28 Zpráva Nejvyššího soudu Slovenské socialistické republiky ze dne 21. prosince 1978, sp. zn. Cpj 37/78, [R 1/1979 civ.]. 
závěru dospěl i Ústavní soud. ${ }^{29}$ Protože ustanovení $§ 40$ odst. 1 OZ50 předepisovalo velmi široce pro veškeré právní jednání o právech $\mathrm{k}$ nemovitostem písemnou formu, ${ }^{30}$ musela být tato podmínka nejspíše dodržena i v případě derelikce. Naproti tomu OZ64 ve znění účinném do 31. prosince 1991 žádnou zvláštní formu opuštění nemovitosti nevyžadoval, mohlo k ní dojít i konkludentně, samozrejmě za předpokladu existence svobodné vůle vlastníka vzdát se svého práva. ${ }^{31}$

Novela OZ64 provedená zákonem č. 509/1991 Sb. s účinností od 1. ledna 1992 sice podstatně změnila právní úpravu derelikce, bohužel však nelze hovořit o kvalitativním posunu. Ustanovení $§ 135$ odst. 3 OZ64 přirovnalo věci opuštěné k věcem skrytým: „Ustanovení odstavce 1 a 2 platí přiměřeně i na věci skryté, jejichž vlastník není znám, a na věci opuštěné.“ Na oba př́ípady se mělo analogicky aplikovat ustanovení § 135 odst. 1 OZ64 o nálezu: „Kdo najde ztracenou věc, je povinen ji vydat vlastníkovi. Není-li vlastník znám, je nálezce povinen odevzdat ji příslušnému státnímu orgánu. Nepřihlásí-li se o ni vlastník do jednoho roku od jejího odevzdání, připadá věc do vlastnictví státu. “ Nešt’astná legislativní práce přispěla spíše ke zmatení pojmů než k vyjasnění právní regulace. Mezi právními civilisty se objevil názor, že opuštění nemovitostí není dle OZ64 vůbec možné, a to bez ohledu na to, zda byly zapsány v katastru nemovitostí. ${ }^{32}$ Lze však najít také opačný postoj, ${ }^{33} \mathrm{k}$ němuž se připojila i soudní praxe. Protože se judikatura nemohla opřít o jednoznačná ustanovení občanského zákoníku, musela mezery v zákoně překlenout odkazem na civilněprávní a rrímskoprávní teorii, byt' ji, zdá se, nijak podrobně nezkoumala a zůstala spíše v rovině obecných pouček. ${ }^{34}$ Derelikci nicméně vyložila jako jednostranné právní jednání, kterým se vlastník vzdává svého vlastnického práva k určité věci. Měla přitom vedle obecných náležitostí kladených na právní jednání naplňovat také vůli vzdát se vlastnictví věci a její fyzické opuštění. V kontinuitě se zněním OZ64 do konce roku 1991 připadaly i po 1. lednu 1992 veškeré opuštěné věci státu, od 1. října 2005 pak obci. Jejich volná okupace nepřicházela v úvahu.

\section{Okamžik pozbytí vlastnického práva}

Po obecných podmínkách opuštění nemovitosti je třeba se zastavit u otázky, kterým okamžikem se stává derelikce účinnou. Za pozornost stojí, že byla obsáhle řešena již ve starověkém Ř́mě, stala se dokonce předmětem sporu škol Sabiniánů a Prokuliánů: Sed Proculus non desinere eam rem domini esse, nisi ab alio possessa fuerit: Iulianus desinere quidem omittentis esse, non fieri autem alterius, nisi possessa fuerit, et recte. ${ }^{35}$ Prokuliáni

29 Nález Ústavního soudu ze dne 26. dubna 2005, sp. zn. I. ÚS 696/02.

$30 \S 40$ odst. 1 OZ50: „Písemné formy je třeba u právních úkonů o právech k nemovitostem, ledaže jde o nájem rodinného domku nebo jiné podobné stavby anebo jen části budovy..."

31 A contrario $\S 46$ odst. 1 OZ64 ve znění účinném do 31. prosince 1991. Viz usnesení Nejvyššího soudu ze dne 24. srpna 2005, sp. zn. 28 Cdo 2730/2004.

32 KNAPPOVÁ, M. - ŠVESTKA, J. Občanské právo hmotné, svazek I. Třetí aktualizované a doplněné vydání. Praha: ASPI Publishing, 2002, s. 306.

33 ŠVESTKA, J. - SPÁČIL, J. - ŠKÁROVÁ, M. - HULMÁK, M. a kol. Občanský zákoník I. 2. vydání. Praha: C. H. Beck, 2009, s. 781-782.

34 Rozsudek Nejvyššího soudu ze dne 11. března 2009, sp. zn. 28 Cdo 3563/2008, [PR 10/2009 s. 373], rozsudek Nejvyššího správního soudu ze dne 7. května 2008, č. j. 2 As 74/2007-55, [1633/2008 Sb. NSS].

35 D. 41, 7, 2, 1 (Paul. 54 ad ed.): „Proculus se ale domnívá, že věc nepřestává patřit vlastníkovi, dokud její držbu nenabude někdo jiný. Iulianus [naproti tomu říká], že přestává [patřit vlastníkovi], když ji opustí, 
měli zastávat názor, že vlastnické právo dosavadního vlastníka nezanikalo prostým faktickým opuštěním věci, nýbrž teprve okamžikem, kdy se jí někdo jiný ujal. Sabiniáni, jež reprezentuje představitel jejich školy Iulianus, naopak přisuzovali derelikci účinky ztráty vlastnického práva a uznávali, že opuštěná věc v mezičase do doby, než byla někým jiným okupována, skutečně neměla žádného vlastníka. ${ }^{36}$ Prameny římského práva ale vzbuzují ještě další pochybnosti ohledně určení okamžiku, kdy docházelo k pozbytí vlastnického práva k opuštěné věci a jeho novému nabytí. Zatímco obvyklé zjednodušené pojetí hovoří o nabytí opuštěných věcí okupací, nelze přehlédnout fragmenty obsažené v Digestech, které se věnují jejich vydržení. ${ }^{37}$ Zdá se, že alespoň v klasickém právu bylo nutné rozlišovat mezi nabýváním některých derelikvovaných věcí okupací a jiných vydržením, právní romanisté však nejsou zajedno v tom, jaké kritérium oba nabývací způsoby oddělovalo. ${ }^{38}$

Větší míra jistoty již panuje ohledně pravidel práva justiniánského, které se prriklonilo ke stanovisku Sabiniánů: Qua ratione verius esse videtur et, si rem pro derelicto a domino habitam occupaverit quis, statim eum dominium effici. pro derelicto autem habetur quod dominus ea mente abiecerit, ut id rerum suaram esse nollet, ideoque statim dominus esse desinit. ${ }^{39}$ Vlastnické právo se ve většině případů pozbývalo již samotnou derelikcí, zájemce pak mohl věc volně okupovat a nabýt ji do vlastnictví uchopením bez nutnosti čekat na uplynutí vydržecí doby. Lze tedy tvrdit, že při posuzování platnosti provedení derelikce byl důraz kladen především na vůli původního vlastníka.

Spory ohledně určení okamžiku, kdy vůle vlastníka věc opustit působila právní následky, byly vedeny také za účinnosti ABGB. Je pravdou, že pochybnosti nepanovaly ohledně nemovitostí, jež nebyly evidovány ve veřejných seznamech. Pro ně platila nepochybně pravidla pro derelikci movitých věcí, vyžadoval se dostatečně určitý projev vůle opouštějícího vlastníka a vzdání se držby. V případě nemovitostí vedených v pozemkových knihách bylo ale třeba vyjasnit vztah derelikce s intabulační zásadou a podobně jako ve starověkém Římě vznikl spor o okamžik pozbytí vlastnického práva. Na jedné straně stál například Antonín Randa, podle něhož měla být upřednostněna vůle vlastníka a okamžik jejího projevení. ${ }^{40}$ Při splnění obecných podmínek derelikce měl pozbýt vlastnické právo bez ohledu na to, že v pozemkových knihách zůstával nadále jako vlastník veden. Naproti tomu František Rouček ${ }^{41}$ kladl důraz na intabulační zásadu vyplývající z ustanovení § 444 ABGB: „Vlastnictví vůbec může zaniknouti vưlí vlastníkovou; zákonem; a soudcovským výrokem. Vlastnictví nemovitých věcí však zaniká jen výmazem z veřejných knih.“ Dovozoval, že vlastnické právo zanikalo teprve výmazem, který musel být řádně navržen, nikoli mimoknihovně. Ve prospěch tohoto názoru hovořilo i ustanovení $§ 350$

ale nezačne patřit jinému, dokud nezíská držbu věci, a má pravdu. “ Srov. D. 47, 2, 43, 5 (Ulp. 41 ad sab.); D. 9, 4, 38, 1 (Ulp. 37 ad ed.).

36 HEYROVSKÝ, op. cit., s. 340.

37 Např́lklad D. 41, 7, 4 (Paul. 15 ad sab.).

38 Více viz FRUTHOVÁ, V. - NOVÁK, M. Originární způsoby nabývání vlastnictví v řmském právu a dnes. Praha: Auditorium, 2018, s. 45-49. KASER, op. cit., s. 426.

39 Inst. Iust. 2, 1, 47: „Proto se zdá být spravedlivějším, aby se někdo stal vlastníkem v okamžiku zmocnění se věci, kterou vlastník považuje za opuštěnou. Za opuštěné je považováno to, čeho se vlastník zbavil s úmyslem, aby to více nebylo součástí jeho majetku a z tohoto důvodu přestává být hned vlastníkem.“ Srov. D. 41, 7, 1 (Ulp. 12 ad ed.).

40 RANDA, op. cit., s. 65.

41 ROUČEK - SEDLÁČEK et al., op. cit., s. 384-385. 
ABGB, které zdůrazňovalo význam tabulární držby: „Držba těch práv a nemovitých věcí, které jsou předmětem veřejných knih, zaniká, když byly ze zemských desk, z městských nebo pozemkových knih vymazány; nebo když byly zapsány na jméno jiné osoby. "V této logice nebylo možné provést derelikci evidované nemovitosti, jež zahrnovala nejen úmysl jednajícího, ale i vzdání se držby věci, bez toho, aby byl opouštějící vlastník z pozemkové knihy vymazán.

Praktickému provedení derelikce nemovitých věcí evidovaných v pozemkových knihách poněkud nepochopitelně bránil právní názor císařského a královského Nejvyššího soudu vyjádřený v ojedinělém rozhodnutí z roku 1898. ${ }^{42}$ Materiálně sice soud možnost provedení derelikce uznal, nepřipustil ale výmaz vlastnického práva v pozemkové knize bez toho, aby došlo ke vkladu ve prospěch vlastníka nového. Byt’ sám svůj výklad označil za formalistický, uvedení nového vlastníka pokládal za nutnou náležitost návrhu na výmaz. Zdá se, že tento právní názor nenašel prŕlišnou odezvu, protože komentář Františka Roučka a Jaromíra Sedláčka jednak derelikci evidovaných nemovitostí považoval za př́pustnou, a dále konkretizoval podobu extabulace tak, že opouštěná nemovitost měla být v pozemkových knihách označena jako věc ničí. ${ }^{43}$ Formalistický přístup Nejvyššího soudu byl překonán i v současném rakouském právu. Tamní právní věda i judikatura se dále při interpretaci ABGB (relevantní ustanovení neprošla po dobu účinnosti ABGB výraznějšími úpravami) kloní k závěru o konstitutivním účinku intabulace při opuštění nemovitosti evidované ve veřejném seznamu. ${ }^{44}$ Derelikce se stává účinnou teprve zaznamenáním v pozemkových knihách. S ohledem na to, že se opuštěním nemovitost stává věcí ničí, jež může být kýmkoli okupována, nelze do veřejného seznamu vložit nového vlastníka, nestačí však ani bez dalšího vymazat vlastníka stávajícího, protože by došlo k obnovení práv vlastníků předchozích. Do pozemkových knih se proto výslovně zapisuje samotná skutečnost opuštění věci (Herrenlosigkeit), jíž se dává najevo, že jde o res nullius.

Za pozornost stojí, že zatímco současné rakouské právo trvá na nutnosti intabulace, československá právní věda ji v průběhu prací na rekodifikaci občanského práva mínila opustit. Návrh subkomitétu pro revisi občanského zákoníku z roku 1923 se ještě tímto směrem neubíral, vyjasňoval alespoň dosavadní spory, když jednoznačně přiznal intabulaci při provádění derelikce konstitutivní účinky a předpokládal možnost zápisu vzdání se vlastnického práva do pozemkových knih v souladu s výše představeným postojem Františka Roučka a současné interpretace ABGB v Rakousku. ${ }^{45}$ Superrevisní komise již v návrhu občanského zákoníku z roku 1931 ve snaze přiblížit podmínky opuštění movitých a nemovitých věcí vypustila nutnost provádět derelikci v pozemkových knihách: „Co do zapsaných nemovitostí nepovažuje superrevisní komise ani za praktické ani za vhodné a nutné,

42 Rozhodnutí císařsko-královského Nejvyššího soudu ze dne 3. května 1898, GIUNF 151. Dostupné ve sbírce Glaser/Unger Neue Folge: Sammlung von Civilrechtlichen Entscheidungen des $k$. $k$. obersten Gerichtshofes. Neue Folge, I. Band. Wien: Verlag der Manz'schen k. u k. Hof-Verlags- und UniversitätsBuchhandlung, 1900, s. 258-259. Srov. ROUČEK - SEDLÁČEK et al., op. cit., s. 385.

43 ROUČEK - SEDLÁČEK et al., op. cit., s. 384-385.

44 Rozhodnutí Nejvyššího soudu Rakouské republiky (Beschluss des Obersten Gerichtshofs) ze dne 29. září 1998, sp. zn. 5 Ob 126/98k. RUMMEL, P. Kommentar zum Allgemeinen bürgerlichen Gesetzbuch mit IPR-Gesetz, Ehegesetz, Mietrechtsgesetz, Wohnungseigentumsgesetz, Landpachtgesetz, Konsumentenschutzgesetz, Produkthaftungs-gesetz, UN-Kaufrecht in zwei Bänden. Bd 1, $\S 1$ bis 1174 $A B G B$. 2. neubearb. und erw. Aufl. Wien: Manz, 1990, s. 451.

45 STIEBER, op. cit., s. 23, 24, 84. 
aby se jich derelikce ve veřejných knihách prováděla. “46 V ustanovení § 300 odst. 1 návrhu bylo počítáno s obecným konstatováním možnosti derelikce a přivlastnění všech věcí, ustanovení § 301 návrhu pak výslovně pamatovalo na možnost domáhat se uvedení knihovního stavu do souladu se skutečným stavem právním. Intabulace tak měla mít toliko deklaratorní povahu. ${ }^{47}$ Vládní návrh občanského zákoníku z roku 1937 toto rozhodnutí následoval a intabulaci jako podmínku opuštění nemovitostí nezakotvoval. V ustanovení § 159 pak v logické návaznosti umožňoval opravu evidovaného stavu do souladu s realitou: „Přivlastní-li si někdo opuštěnou věc zapsanou ve veřejné knize, může se domáhati, aby knihovní stav byl uveden v soulad se skutečným stavem právním. "48 V tomto ohledu na právní teorii navázal socialistický zákonodárce v OZ50, z něhož povinnost intabulace nevyplývala, ${ }^{49}$ což koresponduje s všeobecným opuštěním intabulační zásady v prŕípadech převodu vlastnictví. Z ustanovení § 119 a $§ 132$ odst. 1 OZ50 lze dovodit, že vlastnické právo ke všem nemovitostem jako věcem nikoli nepatrné hodnoty získával stát okamžikem jejich opuštění. OZ64 ve znění účinném do 31. prosince 1991 vycházel ze stejných zásad. Stát nabýval na základě ustanovení § 453 odst. 2 OZ64 vlastnické právo již samotnou derelikcí, jeho souhlas s opuštěním věci ani zápis vlastnického právo do evidence nemovitostí se k účinnosti nabytí vlastnického práva nevyžadoval. ${ }^{50}$

OZ64 po novele s účinností od 1. ledna 1992 v ustanovení § 135 odst. 1 určoval za vlastníka opuštěných věcí stát, od 1. ř́jna 2005 pak obec. Protože pojem věci ničí nebyl v občanském zákoníku upraven, vycházela právní teorie i judikatura ze závěru, že vlastnické právo nabýval stát, respektive obec již samotným okamžikem derelikce. ${ }^{51}$ Podle převažujícího názoru se však derelikce nemovitostí evidovaných v katastru nemovitostí prováděla vkladem. ${ }^{52}$ Oproti dřívějšímu deklaratornímu zápisu do evidence nemovitostí měl vklad do katastru nemovitostí konstitutivní povahu a byl nutnou podmínkou pro zánik vlastnického práva. Tento výklad vychází z ustanovení § 2 odst. 2 zákona č. 265/1992 Sb., o zápisech vlastnických a jiných věcných práv k nemovitostem, účinného od 1. ledna 1993, podle něhož vlastnické právo a další práva k nemovitostem evidovaným v katastru nemovitostí „,vznikají, mění se nebo zanikají dnem vkladu do katastru, pokud občanský zákoník nebo jiný zákon nestanoví jinak“. Z OZ64 pak žádná speciální pravidla nevyplývala. Je vhodné zdůraznit, že požadavek intabulace při opuštění nemovitosti se objevil teprve s účinností zákona č. 265/1992 Sb. a vznikem katastru nemovitostí jako náhrady evidence nemovitostí, tedy rok po velké novele občanského zákoníku. Naproti tomu nemovitosti neevidované ve veřejném seznamu bylo lze opustit neformálním projevem vůle, stejně jako movité věci. Již tímto jednáním se jejich vlastníkem stal stát, později obec.

46 Zákon, kterým se vydává všeobecný zákoník občanský: návrh superrevisní komise. Díl II. Důvodová zpráva. V Praze: Nákladem ministerstva spravedlnosti, 1931, s. 125.

47 Zákon, kterým se vydává všeobecný zákoník občanský: návrh superrevisní komise. Díl I. Tekst zákona, op. cit., s. 89 (§ 300-301).

48 Senát Národního shromáždění R. Čs. r. 1937, tisk 425, vládní návrh zákona, kterým se vydává občanský zákoník, op. cit.

49 Srov. rozsudek Nejvyššího soudu ze dne 1. července 2009, sp. zn. 22 Cdo 4484/2007, [PR 23/2009 s. 857].

50 Usnesení Nejvyššího soudu ze dne 29. dubna 2015, sp. zn. 22 Cdo 157/2015.

51 Rozsudek Nejvyššího soudu ze dne 11. března 2009, sp. zn. 28 Cdo 3563/2008, [PR 10/2009 s. 373], rozsudek Nejvyššího správního soudu ze dne 7. května 2008, č. j. 2 As 74/2007-55, [1633/2008 Sb. NSS].

52 ŠVESTKA - SPÁČIL - ك̌KÁROVÁ - HULMÁK a kol., op. cit., s. 781-782. 


\section{Derelikce nemovitosti v současnosti}

Platný občanský zákoník zčásti napravuje chyby svých předchůdců, když systematickým členěním odlišuje věci opuštěné od ztracených a skrytých, nicméně neposkytuje podrobnější informace o derelikci ani o jejím provedení. Z ustanovení § 1045 odst. 1 OZ jednoznačně vyplývá, že vlastník může na základě svého volného uvážení aktivně opustit movitou věc, jež se tím okamžikem stává res nullius a je k dispozici ostatním lidem, kteří k ní mohou nabýt vlastnické právo okupací. Opuštěné nemovitosti naopak připadají státu ex lege na základě ustanovení § 1045 odst. 2 OZ, nabývá je originárním způsobem. S ohledem na princip vyloučení redundance je tedy nesporné, že za nějakých okolností musí být opuštění nemovitostí možné, bez ohledu na to, zda jsou evidovány v katastru nemovitostí. Tímto závěrem zákonodárce navázal na právní názor Ústavního soudu, který ještě za účinnosti OZ64 identifikoval právo věc opustit (ius dereliquendi) jako součást obsahu vlastnického práva. Stejně jako má vlastník právo na ochranu svého majetku, má rovněž právo se rozhodnout, že věc nadále vlastnit nechce. Udržet si vlastnické právo není jeho povinností. Literatura si všímá, že ustanovení § 1045 odst. 1 OZ používá formulaci „,věc, která nikomu nepatřri“ a vyhýbá se pojmu vlastnického práva. ${ }^{53}$ Žádný zásadní dopad tomu však přičitat nelze. Důvodová zpráva objasňuje, že občanský zákoník tuto formulaci upřednostňuje před údajně archaickými výrazy „věc ničíi“ a „,věc bez pána“, každopádně mezi nimi nenaznačuje žádný rozdíl ve významu.

Derelikce je právním jednáním, které předpokládá svobodnou vưli vlastníka vzdát se vlastnictví věci (animus dereliquendi). ${ }^{54}$ Její existence se podle ustanovení § $1051 \mathrm{OZ}$ nepresumuje: „Má se za to, že si každý chce podržet své vlastnictví...“ Tato vůle musí být manifestována navenek vzdáním se vlastnické držby (corpus derelictionis). Nestačí proto pojmout úmysl věc opustit, ponechává-li si nad ní dosavadní vlastník ve vnějším světě kontrolu. Není překvapivé, že vlastnické právo k movitým věcem a nemovitostem neevidovaným $\mathrm{v}$ katastru nemovitostí vlastník pozbývá prímo právním jednáním, jež vưli věci opustit vyjadřuje. $V$ současnosti však platí totéž i pro nemovitosti vedené ve veřejném seznamu. Jejich derelikce působí zamýšlené účinky, tedy pozbytí vlastnického práva dosavadním vlastníkem a zároveň jeho nabytí státem, okamžitě bez nutnosti intabulace. ${ }^{55}$ Vklad vlastnického práva státu do katastru nemovitostí má jen deklaratorní povahu, s ohledem na ustanovení § $1105 \mathrm{OZ}$ působí konstitutivně jen u převodu vlastnického práva, nikoli v př́padě originárního nabytí. Tímto se současná právní úprava odlišuje od právní teorie vykládající $\mathrm{ABGB}$, která derelikci spojovala teprve s výmazem z veřejných knih. Vyvolává také otázku, jaký význam lze přičítat tabulární držbě56 spočívající v tom, že je určitá osoba $\mathrm{v}$ katastru vedena jako vlastník nemovitosti. $\mathrm{V}$ okamžiku derelikce bude sice dosavadní vlastník vyjadřovat vůli věc nadále nevlastnit a vzdá se její držby, zároveň se ale ke svému majetku bude v katastru nemovitostí nadále veřejně hlásit. Není jen technickou

53 SKŘEJPEK, M. - BĚLOVSKÝ, P. - ŠEJDL, J. - FALADA, D. Římské právo v občanském zákoníku. Komentář a prameny. Věcná práva. Praha: Auditorium, 2017, s. 109.

54 ROUČEK - SEDLÁČEK et al., op. cit., s. 382.

55 FRANKOVÁ, M. Několik poznámek k problematice opuštění nemovitosti. Časopis pro právní vědu a praxi, 2014, 2, s. 111. TÉGL, P. - MELZER, F. K rozsudku NS ve věci opuštění nemovité věci. Bulletin advokacie, 2020, 3, s. 64-65. Srov. rozsudek Nejvyššího soudu ze dne 27. února 2019, sp. zn. 21 Cdo $2257 / 2018$

56 Srov. § $350 \mathrm{ABGB}$. 
záležitostí, zda a jak rychle podá návrh na vklad vlastnického práva státu. Může tak jistě učinit a bude to nejspíše obvyklé, těžko by však byl v případě dlouhého otálení za svou nečinnost vưči katastru nemovitostí penalizován tím, že by se již dříve provedená derelikce začala označovat za neúplnou a neplatnou. Současný př́stup pracující s mimoknihovním zánikem vlastnického práva k opouštěné věci vlastně roli tabulární držby přehlíží.

Sporná zůstává forma právního jednání provádějícího derelikci. Vzhledem k tomu, že u nemovitostí evidovaných v katastru bude účelné, aby jednání zároveň splňovalo náležitosti vkladové listiny, v praxi bude obvykle dostávat požadavkům katastrálního zákona. Protože však k pozbytí vlastnického práva dochází mimoknihovně, mohou nastávat situace, kdy bude nemovitost, at' už evidovaná ve veřejném seznamu či nikoli, platně opuštěna bez toho, aby právní jednání derelikci provádějící tyto podmínky naplňovalo. Právnická obec zpočátku trvala na nutnosti písemné formy ${ }^{57}$ s odkazem na ustanovení $§ 560$ OZ: „Písemnou formu vyžaduje právní jednání, kterým se zřizuje nebo převádí věcné právo k nemovité věci, jakož i právní jednání, kterým se takové právo mění nebo ruší. “ Nejvyšší soud naopak konstatoval, že se toto pravidlo na derelikci neaplikuje. 58 Právní jednání, jímž je nemovitost opouštěna, tedy nemusí být písemné, postačí jakákoliv srozumitelná a určitá forma, včetně konkludentního jednání. Toto pravidlo upřednostňuje vůli dosavadního vlastníka, kterého při jeho jednání nesvazuje žádnými náležitostmi, zároveň ho zbavuje povinnosti být schopný zpětně provedení derelikce prokázat. Každý vlastník se tak svým způsobem může připodobnit Schrödingerově kočce a podle potřeby tvrdit, že nemovitost v daném okamžiku nevlastní, protože ji před několika dny neformálním projevem vůle opustil. Je však nutno přiznat, že z hlediska dokazování by nijak nepomohlo, kdyby derelikce musela být prováděna písemnou formou bez nutnosti zahájit katastrální řízení. Stejně jako si každý může vymyslet neformální derelikci provedenou v minulosti, není nemožné antidatovat listinu, jež by nebyla nijak evidována ani ověřována.

V praxi působila největší potíže otázka, jakým způsobem má být právo opustit nemovitost evidovanou ve veřejném seznamu realizováno. Český úřad zeměměřický a katastrální v interním pokynu svým zaměstnancům uložil, ${ }^{59}$ aby v př́padě derelikce nemovitostí zapisovali do katastru nemovitostí vlastnické právo České republiky výhradně na základě souhlasného prohlášení státu a dosavadního vlastníka. Vycházel z poněkud formalistického výkladu ustanovení § 66 odst. 1 vyhlášky č. 357/2013 Sb., o katastru nemovitostí, podle něhož v situacích, kdy zákon stanoví, že právo zapisované do katastru vzniká, mění se nebo zaniká na základě určité právní skutečnosti nezávisle na zápisu do katastru, ale nestanoví listinu, na jejímž základě se tato změna zapíše do katastru, lze provést zápis na základě souhlasného prohlášení učiněného osobou, jejíž právo zapsané dosud v katastru zaniklo, a osobou, jejíž právo naopak vzniklo. Mělo to platit také pro derelikci, u níž není žádná vkladová listina zákonem specifikována. ${ }^{60}$ Jednostranná prohlášení o derelikci kata-

57 ŠVESTKA, J. - DVOŘÁK, J. - FIALA, J. a kol. Občanský zákoník: komentářr, svazek III (\$ 976-1474). Praha: Wolters Kluwer ČR, 2013, ad § 1045. ELIÁŠ, K. Opuštění nemovitosti: vlastníci se bát nemusejí. Právo, 16. listopadu 2012, s. 21. FRANKOVÁ, op. cit., s. 111.

58 Rozsudek Nejvyššího soudu ze dne 27. února 2019, sp. zn. 21 Cdo 2257/2018, rozsudek Nejvyššího soudu ze dne 21. srpna 2019, sp. zn. 24 Cdo 3337/2018.

59 Srov. rozsudek Krajského soudu v Praze ze dne 31. května 2019, č. j. 38 C 170/2016-190.

60 Dříve než Nejvyšší soud na tento problém upozorňovala Martina Franková: FRANKOVÁ, op. cit., s. $113-114$. 
strální úrady nepovažovaly za zpo̊sobilou vkladovou listinu podle ustanovení § 17 zákona č. 256/2013 Sb., o katastru nemovitostí, a návrhy na vklad vlastnického práva podané opouštějícím vlastníkem zamítaly. Zprvu tento výklad v ř́zeních podle části V. občanského soudního řádu, přezkoumávajících rozhodnutí katastrálních úřadů o zamítnutí návrhu na vklad vlastnického práva, podpořily některé krajské soudy i Vrchní soud v Praze. ${ }^{61}$ Patrně vlivem nejistoty ohledně nové právní úpravy a přenositelnosti starší judikatury vyčítaly navrhovatelům absenci souhlasu státu s návrhem na vklad vlastnického práva a zdůrazňovaly nutnost předložit souhlasné prohlášení. Samotné jednostranné prohlášení o derelikci, byt' dokonce formou notářského zápisu, ke vkladu nepostačovalo. Symptomatické je, že ačkoli na rozdíl od katastrálních úřadů nebyly soudy při rozhodování vázány podzákonnými předpisy, tedy ani katastrální vyhláškou, následovaly její dikci i za cenu popření smyslu institutu derelikce a neupřednostnily na její úkor občanský zákoník. Je však vhodné zdůraznit, že tento požadavek kladly soudy na vkladovou listinu pro účely vkladového rrízení. Nepopíraly výslovně, že materiálně k derelikci mohlo dojít jednostranným projevem vůle.

Interpretace katastrálních úřradů i soudů sice brala ohledy na znění katastrální vyhlášky, znatelně ale omezovala práva vlastníka s věcí libovolně nakládat, když mu neumožnila derelikci řádně promítnout do katastru nemovitostí. Jednoznačné opuštění nemovitosti s účinky vưči třetím osobám bylo podmíněno předložením dvoustranného souhlasného prohlášení, čímž byla derelikce de facto zbavena charakteru jednostranného právního jednání: „Jestliže tedy stát legislativně připustil existenci institutu derelikce jakožto jednostranného právního jednání, jehož účinky nastanou okamžikem jeho uskutečnění a nezasáhnou do právního postavení jiného (vyjma jeho samotného), pak ovšem není žádný rozumný důvod pro účely zápisu právních účinků tohoto jednání do veřejného seznamu je stavět na roveň právního jednání dvoustranného (tedy vyžadovat jeho akceptaci tím, na něhož opuštěná věc přešla). "62 Derelikce tak byla připodobněna k bezúplatnému převodu, což by ovšem vyprázdnilo smysl tohoto institutu. Proti se proto ostře postavil Nejvyšší soud, který poměrně široce vyložil povahu derelikce a přiměl katastrální úřady ke změně dřívější praxe. ${ }^{63}$ Nyní již konstantní judikatura označuje opuštění věci za jednostranné právní jednání, které v případě nemovitostí nevyžaduje souhlas státu jako nabyvatele majetku. Z katastrální vyhlášky, která je s občanskoprávní úpravou nekompatibilní a s př́ípady derelikce pochybením zákonodárce vůbec nepočítá, nelze vyvozovat zpř́isnění podmínek opuštění nemovitosti. Vyplývá-li charakter jednostranného jednání př́ímo z občanského zákoníku, nemůže podzákonný předpis taxativně omezit výčet vkladových listin tak, že fakticky

61 Rozsudek Krajského soudu v Praze ze dne 21. dubna 2017, č. j. 38 C 170/2016-115, rozsudek Vrchního soudu v Praze ze dne 18. ledna 2018, č. j. 4 Co 169/2017-147, rozsudek Městského soudu v Praze ze dne 31. října 2016, č. j. 33 C 10/2015-25, rozsudek Vrchního soudu v Praze ze dne 7. prosince 2017, č. j. 4 Co 39/2017-51, rozsudek Vrchního soudu v Praze ze dne 4 Co 14/2017-69, rozsudek Krajského soudu v Českých Budějovicích ze dne 27. září 2017, č. j. 11 C 2/2017-61, rozsudek Městského soudu v Praze ze dne 27. února 2017, č. j. 26 C 9/2016-23. Naopak s budoucím výkladem Nejvyššího soudu souzní rozsudek Krajského soudu v Hradci Králové ze dne 11. listopadu 2016, č. j. 16 C 70/2016-35, a ohledně jednostranné povahy derelikce i rozsudek Krajského soudu v Ústí nad Labem ze dne 29. ledna 2016, č. j. 90 C 18/2015-17.

62 Rozsudek Nejvyššího soudu ze dne 27. února 2019, sp. zn. 21 Cdo 2257/2018.

63 Rozsudek Nejvyššího soudu ze dne 27. února 2019, sp. zn. 21 Cdo 2257/2018, rozsudek Nejvyššího soudu ze dne 21. srpna 2019, sp. zn. 24 Cdo 3337/2018, rozsudek Nejvyššího soudu ze dne 11. zář́i 2019, sp. zn. 24 Cdo 183/2019-II. 
nebude možné dosáhnout vkladu vlastnického práva státu k opuštěné nemovitosti: „Nejvyšší soud zde judikoval, že vyjma listiny uvedené v § 66 odst. 1 písm. a) kat. vyhlášky (souhlasné prohlášení) je listinou, podle které lze zápis práva do katastru vkladem provést, jakákoli listina v písemné či elektronické podobě, která obsahuje obligatorní náležitosti dle $\S 8$ kat. zák., jejíž obsah odůvodňuje navrhovaný vklad (§ 17 odst. 1 písm. b) kat. zák., resp. $\S 17$ odst. 2 písm. b) tohoto zákona) a která splňuje náležitosti uvedené v $§ 17$ odst. 2, 3 kat. zák."64

Alternativní pohled nabídli Petr Tégl a Filip Melzer, kteří by povolení vkladu vlastnického práva státu na souhlasné prohlášení vázali. ${ }^{65} \mathrm{~S}$ poukazem na to, že stát nabývá vlastnické právo k opuštěné nemovitosti mimoknihovně, tedy bez nutnosti intabulace, odlišují právní jednání vedoucí k derelikci a listinu způsobilou promítnout změnu vlastnického práva do katastru nemovitostí. Zatímco účinky opuštění nemovitosti působí jednostranné právní jednání podle požadavků občanského zákoníku, je podle těchto autorů smysluplné, aby byl vklad vlastnického práva v katastru nemovitostí proveden teprve na základě souhlasného prohlášení. Ještě před zahájením vkladového řízení by tak byla ověřena platnost derelikce a státu by byla dána možnost se proti ní včas bránit.

Katastrální úřady tedy v současnosti provedou vklad vlastnického práva státu do katastru nemovitostí na základě jednostranného prohlášení opouštějícího vlastníka v písemné či elektronické podobě, které obsahuje obligatorní náležitosti listiny pro zápis do katastru uvedené v ustanoveních $\S 7$ a 8 katastrálního zákona. ${ }^{66}$ Katastrální úřad v řízení o povolení vkladu práva do katastru nemovitostí zkoumá předložené prohlášení výhradně z hledisek taxativně vypočtených v ustanovení $§ 17$ odst. 1 katastrálního zákona. Všímá si proto spíše formálních náležitostí, nepřísluší mu zkoumat platnost právního jednání, na základě kterého bylo v katastru nemovitostí zapsáno vlastnické právo státu k opuštěné věci. Stejné omezení platí pro soudní přezkum rozhodnutí úřadu v řízení podle části V. občanského soudního řádu. Ani v něm nejsou soudy oprávněny hodnotit platnost samotné derelikce. Stát o tuto námitku není prripraven, musí ji ale uplatnit v samostatném rrízení, nikoli v ř́zení vkladovém. Striktní oddělní otázky způsobilosti vkladové listiny a platnosti derelikce představené Nejvyšším soudem může vycházet $\mathrm{z}$ oprávněného přesvědčení o složitosti přezkumu později zmíněné otázky. Zdá se, že ve vkladovém řízení u katastrálního úřadu není prostor pro podrobné hodnocení platnosti právního jednání, která může být ohrožena obtížně doložitelnými vadami vůle, nepoctivými úmysly nebo faktickým stavem opouštěné nemovitosti. Na druhou stranu se stanovisko Nejvyššího soudu setkalo s kritikou ${ }^{67}$ pro jeho nepraktičnost a omezené možnosti státu bránit se proti neplatné derelikci. Místo toho, aby mohl stát zasáhnout ještě před vkladem vlastnického práva, bude moct teprve následně zahájit zvláštní řízení, na jehož pravomocné skončení se může čekat několik let. Mezitím mu mohou vznikat nemalé náklady na údržbu nemovitostí, které se bude teprve zpětně pokoušet vymoci po skutečném vlastníkovi.

Obranu státu však bude ztěžovat také to, že se o nabytí vlastnického práva k opouštěným nemovitostem bude dozvídat s časovou prodlevou. Půjde-li o neevidovanou nemovitost, občanský zákoník s výslovnou povinností informovat stát o derelikci vůbec

64 Rozsudek Městského soudu v Praze ze dne 22. ledna 2020, č. j. 33 C 10/2015-97.

65 TÉGL-MELZER, op. cit., s. 64-65.

66 Rozsudek Nejvyššího soudu ze dne 27. února 2019, sp. zn. 21 Cdo 2257/2018.

67 TÉGL - MELZER, op. cit., s. 64-65. 
nepočítá. V případě nemovitostí vedených v katastru se stát bude o nabytí vlastnického práva obvykle dozvídat teprve v průběhu vkladového řízení, tedy s odstupem od okamžiku, kdy derelikce působí účinky. Před podáním návrhu na vklad ze strany opouštějícího vlastníka nemusí být stát o rozšíření svého majetku informován, nebude mít ani možnost nemovitost bezprostředně v okamžiku nabytí vlastnického práva ohledat a formálně převzít. Neseznámí se se stavem opouštěné nemovitosti, přesto za něj bude za určitých okolností odpovědný. Tato paradoxní situace odporující veřejnému zájmu je důsledkem závěru o mimoknihovním nabytí vlastnického práva na základě samotného právního jednání vedoucího k opuštění, ale také toho, že Nejvyšší soud toto jednání označil za neadresné. ${ }^{68} \mathrm{Na}$ související problémy upozornila Martina Franková, podle níž by bylo vhodnější pokládat jej za adresné jednání. ${ }^{69}$ Ve smyslu ustanovení $\S 570$ OZ by šlo o jednání vůči nepř́itomné osobě, které by působilo účinky teprve okamžikem dojití. Stát by sice neměl možnost dosáhnout rychlého přezkumu platnosti derelikce, byl by ale alespoň s nabytím vlastnického práva včas seznámen a mohl by okamžitě začít plnit své zákonné povinnosti. Nejvyšší soud bohužel neobjasňuje, proč se rozhodl zvolit v kontextu dalších charakteristik variantu neadresného právního jednání. Požadavek sdělení úmyslu provést derelikci státu by jistě nepředstavoval závažné narušení svobody vlastníka v nakládání se svým majetkem ani jednostrannost jednání.

Nabízí se však vysvětlení, že Nejvyšší soud ve své praxi přejímá závěry právní teorie formulované v období první poloviny 20. století. Lze skutečně vysledovat, že judikatura posuzující opuštění nemovitosti dle OZ50 a OZ64 si oblíbila odkazy na právní civilistiku a romanistiku, ${ }^{70}$ jejichž prostřednictvím se snažila překlenovat podstatné mezery $\mathrm{v}$ civilních kodexech. Ne z textu zákoníků, ale z odborné literatury judikatura formulovala definici derelikce, která pak prostupuje soudními rozhodnutími do současnosti. Nicméně, stranou pozornosti soudů zůstávají podstatné odlišnosti tehdejší a dnešní právní úpravy. Zatímco se nemovitost opuštěná podle ABGB stávala věcí ničí, kterou mohl kdokoli okupovat, nyní připadá okamžikem derelikce státu. V době účinnosti ABGB proto musela být vůle opustit nemovitost vyjádřena navenek jednostranným neadresným právním jednáním, jež bylo srozumitelné pro neurčitou množinu relevantních aktérů. Ani dnes není vhodné opuštění tajit před ostatními lidmi, nicméně, nemají již možnost věc okupovat, protože připadne nevyhnutelně státu. Změna právní úpravy by mohla vést k přehodnocení některých dosud uplatňovaných výkladů. Ukazuje se navíc, že nabytí opuštěných nemovitostí státem, které by mohlo být prvoplánově vnímáno jako nepřiměřené privilegium, a jež socialistický zákonodárce označoval za př́klon k zájmům společnosti, ${ }^{71}$ je ve skutečnosti vysoce zatěžující povinností. Její smysl primárně nespočívá v zájmu rozmnožování majetku státu, ale v zabránění existence pustnoucích a potenciálně rizikových nemovitostí, jejichž opuštění by bylo dokonce právem aprobováno. Místo tohoto černého scénáře se o ně bude na vlastní náklady ve veřejném zájmu starat stát. Nemožnost obrany státu proti nabytí majetku v důsledku derelikce kontrastuje s ustanovením $§ 12$ odst. 2 zákona č.

\footnotetext{
68 Rozsudek Nejvyššího soudu ze dne 27. února 2019, sp. zn. 21 Cdo 2257/2018, rozsudek Nejvyššího soudu ze dne 21. srpna 2019, sp. zn. 24 Cdo 3337/2018.

69 FRANKOVÁ, op. cit., s. 112.

70 Rozsudek Nejvyššího soudu ze dne 11. března 2009, sp. zn. 28 Cdo 3563/2008, [PR 10/2009 s. 373], rozsudek Nejvyššího správního soudu ze dne 7. května 2008, č. j. 2 As 74/2007-55, [1633/2008 Sb. NSS].

71 Důvodová zpráva k OZ50, ad $\S 119$.
} 
219/2000 Sb., o majetku České republiky a jejím vystupování v právních vztazích, podle něhož je bezúplatný převod hmotné nemovité věci, která se eviduje v katastru nemovitostí, na stát podmíněn souhlasem Ministerstva financí, ${ }^{72}$ zjevně s cílem uchránit jej před nevýhodnými převody. Derelikce v současné podobě umožňuje tento předpis jednoduše obcházet. Jestliže by dosavadnímu vlastníkovi vznikly pochybnosti, zda bude ministerstvo s bezúplatným převodem souhlasit, nabízí se opuštění věci jako snazší a jistější cesta.

Ačkoli judikatura prohlašuje opuštění věci za právo vlastníka a prostupuje ji tendence neklást provedení derelikce překážky, naznačuje i jistá omezení vyplývající ze zákonného požadavku řádně spravovat vlastní majetek: „Princip demokratického právního státu, jak má na mysli čl. 1 odst. 1 Ústavy, vyžaduje, aby státní orgány respektovaly ústavní ochranu vlastnictví (čl. 11 Listiny) a spolehlivě zjišstovaly, zda vůle vlastníka skutečně směřuje k derelikci jeho majetku. Paralelně však každý vlastník nese - v duchu parémie ,vlastnictví zavazuje - odpovědnost za výkon vlastnického práva (tedy i za řádnou správu svého majetku)."73 Zdůrazňuje především, že opuštění věci nesmí odporovat zákonu, obcházet jej či být v rozporu s dobrými mravy. ${ }^{74}$ Hodnocení př́ípustnosti derelikce připomíná výše popsané úvahy zachycené $\mathrm{v}$ pramenech římského práva, které posuzovaly situace, kdy se opouštějící vlastník snažil zbavit svých povinností, např́klad odklizení trosek stavby z cizího pozemku nebo opravy konstrukce nesoucí sousedovu stavbu. Judikatura tato omezení taxativně nevypočítává a nejsou ani výslovně uvedena v ustanoveních občanského zákoníku věnujících se derelikci. Je třeba je vyvozovat z obecných ustanovení, podle nichž se právní jednání s ohledem na ustanovení § 580 odst. 1 a $\$ 588$ OZ nesmí př́ičit dobrým mravům, zjevně narušovat veřejný pořádek ani odporovat zákonu. Opuštění věci nemá být nepoctivé ani protiprávní: „Nikdo nesmí těžit ze svého nepoctivého nebo protiprávního činu. Nikdo nesmí těžit ani z protiprávního stavu, který vyvolal nebo nad kterým má kontrolu.“ (§ 6 odst. 2 OZ) A konečně, žádné právo nesmí být zneužito k újmě druhého: „Zjevné zneužití práva nepožívá právní ochrany.“ (\$ 8 OZ) Jaké konkrétní skutkové okolnosti bude nutné s ohledem na tato obecná omezení označit za apriorně nemorální, nepoctivé, protiprávní či zneužívající právo zatím není jasné. Zdá se, že půjde především o situace, kdy vlastník záměrně obchází zákony, neplní dlouhodobě své povinnosti, snaží se vyhnout odpovědnosti za neúnosný stav nemovitosti a přesunout povinnost jeho nápravy na stát. ${ }^{75}$ Může se jednat např́klad o kontaminované pozemky, na nichž byla ukončena těžba, nebo kde byl uložen odpad, či o stavby s narušenou statikou. ${ }^{76}$ Bude nutné zohlednit, nakolik nese opouštějící vlastník vinu na nedostatečné údržbě nemovitosti, př́ípadně, zda měl dostatek času k nápravě. Význam budou hrát i pohnutky, které ho k derelikci za daných okolností vedly. Stát bude moci tyto okolnosti namítat v ř́zení, které sám zahájí, a v němž se bude domáhat deklarování neplatnosti právního jednání působícího opuštění nemovitosti a obnovy evidence vlastnického práva v katastru nemovitostí. Naopak Nejvyšší soud již potvrdil, že opustit lze i spoluvlastnický podíl k nemovitosti a není třeba zohlednit vůli

\footnotetext{
72 MÁCHA, A. Opuštění nemovitosti - ano, či ne? Právní rozhledy, 2016, 2, s. 52.

73 Nález Ústavního soudu ze dne 26. dubna 2005, sp. zn. I. ÚS 696/02.

74 Rozsudek Nejvyššího správního soudu ze dne 7. května 2008, č. j. 2 As 74/2007-55, [1633/2008 Sb. NSS], rozsudek Nejvyššího soudu ze dne 11. března 2009, sp. zn. 28 Cdo 3563/2008, [PR 10/2009 s. 373].

75 Rozsudek Krajského soudu v Ústí nad Labem ze dne 29. ledna 2016, č. j. 90 C 18/2015-17.

76 CHALUPA, op. cit.
} 
ostatních spoluvlastníků. Z jeho pohledu tedy nejde o problematický, či snad dokonce nepoctivý postup. ${ }^{77}$

Vše výše řečené se týká aktivního opuštění nemovitosti právním jednáním. Nicméně, občanský zákoník v ustanovení § 1050 odst. 2 upravuje také pasivní derelikci nevykonáváním vlastnického práva: „Nevykonává-li vlastník vlastnické právo k nemovité věci po dobu deseti let, má se za to, že ji opustil.“ Zakotvuje vyvratitelnou právní domněnku, která je vázána na desetiletou lhůtu, jež s ohledem na ustanovení § 3067 OZ nepočne běžet dříve než 1 . ledna 2014, kdy občanský zákoník nabyl účinnosti. V současnosti proto ještě není k dispozici judikatura, která by právní úpravu vykládala, první soudní spory lze očekávat teprve v roce 2024, přesto již zmíněná domněnka stihla zaujmout pozornost odborné veřejnosti. Její dopad však nelze přeceňovat. Domněnku opuštění nemovitosti je třeba interpretovat konformně se zásadou nepromlčitelnosti vlastnického práva vyplývající z ustanovení § 614 OZ. ${ }^{78}$ Dosavadní vlastník domněle opuštěné věci bude proto mít možnost domněnku vyvrátit tvrzením, že vlastnické právo vykonává. V souvislosti s ustanovením $§ 1050$ odst. $2 \mathrm{OZ}$ se opětovně nabízí otázka, jakou váhu přičítat tabulární držbě. Karel Eliáš je přesvědčen o tom, že je-li někdo v katastru nemovitostí zapsán jako vlastník, dává tím najevo, že se vlastnictví zbavit nechce a není prostor pro uplatnění vyvratitelné domněnky derelikce. ${ }^{79}$ Tento výklad sice praktickým způsobem chrání vlastnické právo a právní jistotu, není ale jasné, proč by se stejný účinek neměl tabulární držbě přičítat při opuštění nemovitosti právním jednáním. Protože $\mathrm{v}$ takovém př́ípadě k pozbytí vlastnického práva k evidované nemovitosti dochází mimoknihovně a následná intabulace má jen deklaratorní charakter, právní jednání provádějící derelikci se bude vždy odehrávat v době, kdy je ještě stávající vlastník v katastru nemovitostí evidován. Dále je třeba poukázat na to, že vlastníkem opuštěných nemovitostí se stává výhradně stát. Aby mohlo dojít k př́ípadům aplikace ustanovení § 1050 odst. 2 OZ, budou muset státní orgány aktivně vyhledat nemovitosti, jež považují za opuštěné, ujmout se jich a připravit se na případný spor o vykonávání vlastnického práva předchozím vlastníkem. Čas ukáže, nakolik bude mít stát zájem této možnosti využívat. Lze ovšem pochybovat o tom, že by domněnku derelikce nadužíval, obzvláště proto, že sám prostřednictvím Listiny základních práv a svobod garantuje všeobecnou ochranu vlastnického práva.

\section{Závěr}

Z judikatury Nejvyššího a Ústavního soudu vyplývá, že každý má právo opustit nemovitou věc, pokud svého práva nezneužívá a nesnaží se zbavit odpovědnosti za neplnění vlastních povinností. Právní institut derelikce má původ již v římském právu, které kladlo důraz na svobodnou vůli vlastníka rozhodujícího se pro vzdání se vlastnického práva. K derelikci nemovitostí evidovaných i neevidovaných v katastru nemovitostí dochází již samotným právním jednáním, jímž vlastník vyjadřuje vůli pozbýt vlastnické právo. Deklaratorní povahou intabulace zákonodárce pravděpodobně vědomě navázal na rekodifikační práce z 20. a 30. let 20. století, a naopak se odklonil od minulé i současné úpravy ABGB. Na rozdíl od stavu do roku 1950 však následoval socialistického zákonodárce v závěru,

77 Rozsudek Nejvyššího soudu ze dne 11. září 2019, sp. zn. 24 Cdo 183/2019-II.

78 SPÁČIL, J. a kol. Občanský zákoník III. Věcná práva (\$ 976-1474). Praha: C. H. Beck, 2013, s. 265.

79 ELIÁŠ, op. cit. 
že okamžikem opuštění nabývá vlastnické právo k nemovitostem stát. Místo předpokládaného prospěchu, který by byl v zájmu společnosti, však nejspíše státu způsobí těžkosti a dodatečné náklady, které mu budou v souvislosti s nedobrovolným přejímáním mnohých danajských darů vznikat. Zpočátku se objevovaly spory o náležitostech návrhu na vklad vlastnického práva státu do katastru nemovitostí, nicméně bylo objasněno, že derelikci je třeba chápat jako jednostranné jednání, jehož účinky stát svým nesouhlasem není schopen zvrátit. Zbývá mu jen možnost se v samostatném řízení domáhat prohlášení derelikce za neplatnou. Zdá se sice, že opuštění nemovitostí je velmi raritním úkazem, přesto by bylo vhodné uvažovat nad tím, zda by nemělo být zajištěno včasné informování státu o tom, že opuštěný majetek nabývá do vlastnictví, aby se mohl řádně ujmout jeho správy. 